\title{
A CASE OF ADENOID BASAL CELL CARCINOMA IN UTERINE CERVIX
}

\author{
Young Hwa Cho, MD, Ji Hyun Choi, MD, Hyuk Jung, MD, PhD \\ Department of Obstetrics and Gynecology, Chosun University School of Medicine, Gwangju, Korea
}

Adenoid basal cell carcinoma of uterine cervix is very rare disease and is common to postmenopausal women. Adenoid basal cell carcinoma does not make certain type of lesion. So adenoid basal cell carcinoma is hard to find. Differentiation between adenoid basal cell carcinoma from adenoid cystic carcinoma is significant because prognosis of Adenoid basal carcinoma is less severe. We report patient who underwent hysterectomy under the diagnosis of pyometra. She was diagnosed with adenoid basal cell carcinoma by biopsy after surgery.

Keywords: Adenoid basal cell carcinoma, Adenoid cystic carcinoma

자궁 경부의 선양기저세포암(adenoid basal cell carcinoma)은 1966 년 Baggish와 Woodruff [1]에 의해 최초로 보고된, 전체 자궁 경부 선암 의 $1 \%$ 미만에 해당하는 매우 드문 종양이다. 기원에 대해서는 아직 논 란의 여지가 있으나 주로 기저부의 다능성(multipotential) 세포나 경부 상피의 예비(reserve) 세포로부터 분화되었을 것이라고 알려지고 있다 [2]. 자궁 경부의 선양 기저세포암은 대부분이 자궁 경부 상피 내 이형 성증과 관련이 있으며 일반 세포진 검사에서도 발견이 어려운 매우 드 문 질환이다[3]. 그러나 선양 기저세포암은 비교적 전이가 드물며 좋은 예후를 보이므로 예후 면에서는 다른 자궁 경부암과 구별되어야 한다 [4]. 저자들은 농자궁증의 진단 하에 복강경하 질식 자궁절제술 및 양측 부속기절제술을 시행한 고령 환자의 수술 후 조직학적 검사상 선양기저 세포암 1 예를 경험하여 문헌 고찰과 함께 이를 보고하는 바이다.

\section{증 례}

환 자:" 이 $\mathrm{O}$ 임

나 이: 70세

주 소: 내원 일주일 전부터 발생한 농성 질 분비물

월경력: 초경은 16세 전후이며 생리양과 생리통은 보통이었으며 5-6일 정도 지속되었고 51 세에 폐경되었다.

산과력: 6-0-1/0-6 질식 자연분만 6회 하였으며, 한 차례의 인공 유산 기왕력이 있었다.

가족력: 특이 사항 없었다.

과거력: 내원 3년 전 고혈압, 당뇨 진단 받고 현재까지 경구 치료제 복 용 중이며, 간헐적으로 양측 무릎 관절염으로 인해 진통 소염제 및 경구
스테로이드 제제 복용하였으며, 20년 전 늑막염을 않은 후 우측 폐의 섬 유화로 경도의 제한성 환기 장애 진단 받고 기관지 확장제를 복용 중이 었다.

현병력: 2009년 말부터 지속된 농성 질 분비물로 본원 내원 3달 전 개 인 산부인과에서 자궁 경부 세포진 검사 시행하였으나 특이 소견 보이 지 않았고 증상이 있을 때마다 간헐적으로 질 정제, 경구 항생제 등의 치료 받았던 분으로, 내원 일주일 전부터 농성 질 분비물 재발하여 개인 병원에서 입원 치료 시행 중 정밀 검사 위해 본원으로 전원되었다.

이학적 소견 및 내진 소견: 내원 당시 혈압, 맥박, 체온 정상이었으며 양 측 무릎의 관절염으로 약간의 운동 제한 있었으나 비교적 전신 상태는 양호하였다. 복부 촉진 상 자궁이 커져있어 부드럽게 만져졌으며, 양측 부속기는 위축되어 촉지되지 않았다. 질경을 사용한 육안적 검사 상 자 궁 경부는 위축되어 있었고 미란과 출혈 등의 이상 소견은 관찰되지 않

Received: 2010. 9. 3. Revised: 2010.11.26. Accepted: 2010.12. 8. Corresponding author: Hyuk Jung, MD, PhD

Department of Obstetrics and Gynecology, Chosun University of College of Medicine, 588 Seoseok-dong, Dong-gu,

Gwangju 501-709, Korea

Tel: +82-62-220-3092 Fax: +82-62-232-2310

E-mail: bimilo@hanmail.net

This is an Open Access article distributed under the terms of the Creative Commons Attribution Non-Commercial License (http://creativecommons.org/licenses/ by-nc/3.0/) which permits unrestricted non-commercial use, distribution, and reproduction in any medium, provided the original work is properly cited.

Copyright $\odot$ 2011. Korean Society of Obstetrics and Gynecology 


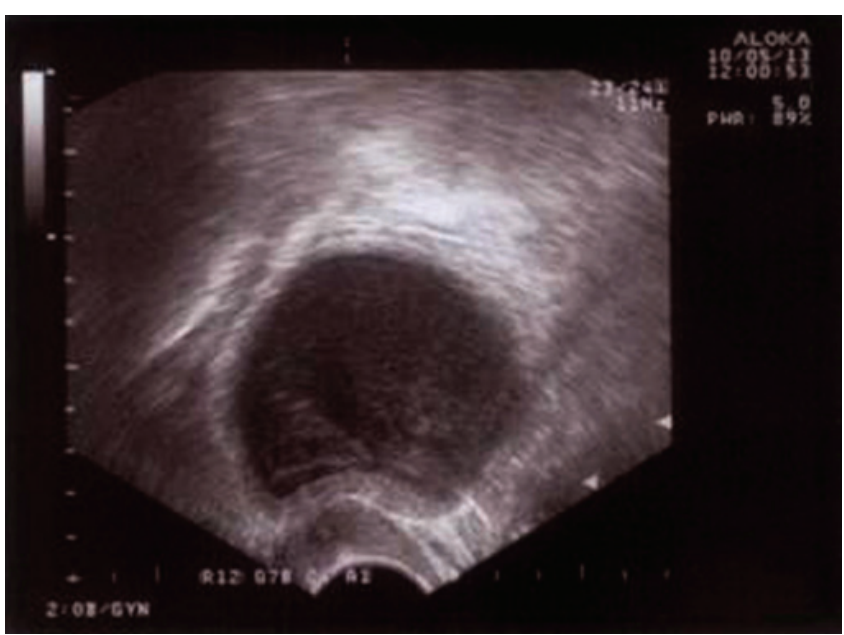

Fig. 1. Transvaginalultrasonographic image of hypoechoic lesion in uterus.

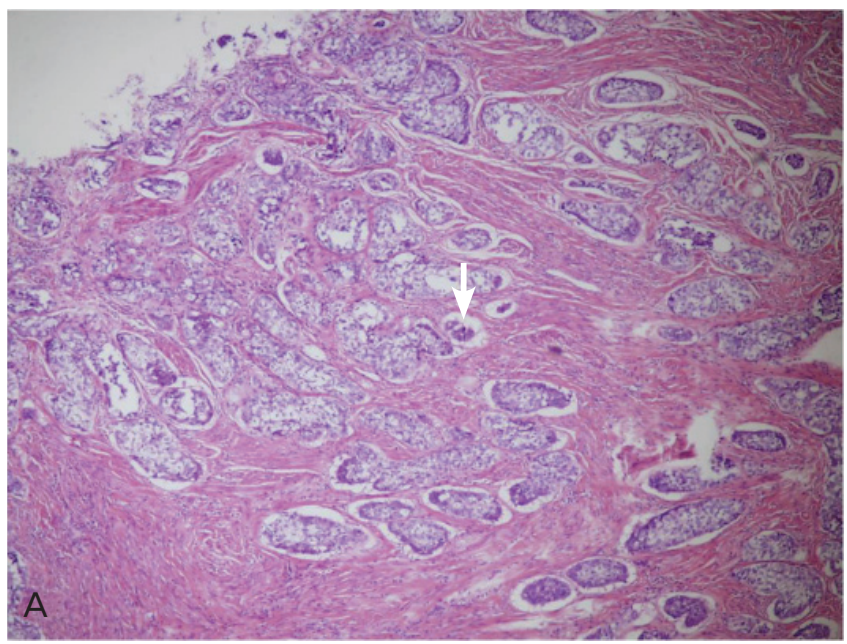

Fig. 3. (A) Low power view of rounded nests of basaloid cells infiltrating muscle layer. The tumor is characterized with small nests with scant cytoplasm $(\downarrow)(H \& E, \times 40)$. (B) Note the peripheral palisading of tumor cells $(\uparrow)$ and gland formation $(\rightarrow)(H \& E, \times 100)$.

았다.

검사 소견: 혈액학 검사상 혈소판 $13.0 \mathrm{~g} / \mathrm{dL}$ 으로 정상 소견 보였으며 백혈구 13,620 (호중구 75\%)/ $\mu$ 로 상승 소견 보였다. 생화학 검사 상 혈당이 $170 \mathrm{mg} / \mathrm{dL}$ 로 소폭 상승된 것 이외에 이상 소견은 없었다. 소변 검사상 백혈구가 검출되었으며, 질 분비물에 대한 미생물학적 배양 검 사에서 질 내 상재균 이외 병원성 세균은 검출되지 않았다. 본원에서 다 시 시행한 자궁경부 세포진 검사에서도 특이 소견 보이지 않았고, 자궁 외경부 조직 검사에서 악성과 관련된 소견 보이지 않았다.

경질 초음파 소견: 자궁은 전굴 상태로 크기는 $11.0 \times 5.0 \mathrm{~cm}$ 정도였으 며 자궁벽은 $0.3 \mathrm{~cm}$ 로 얇아져 있었다. 자궁 내부에 저에코성의 액체 저 류 소견이 보였고, 양측 부속기는 관찰되지 않았다(Fig. 1).

수술 소견: 저자들은 환자가 3 개월 전 개인병원에서 시행한 자궁 경부 세포진 검사와 본원에서 시행한 자궁 경부 세포진 검사, 자궁 외경부 조
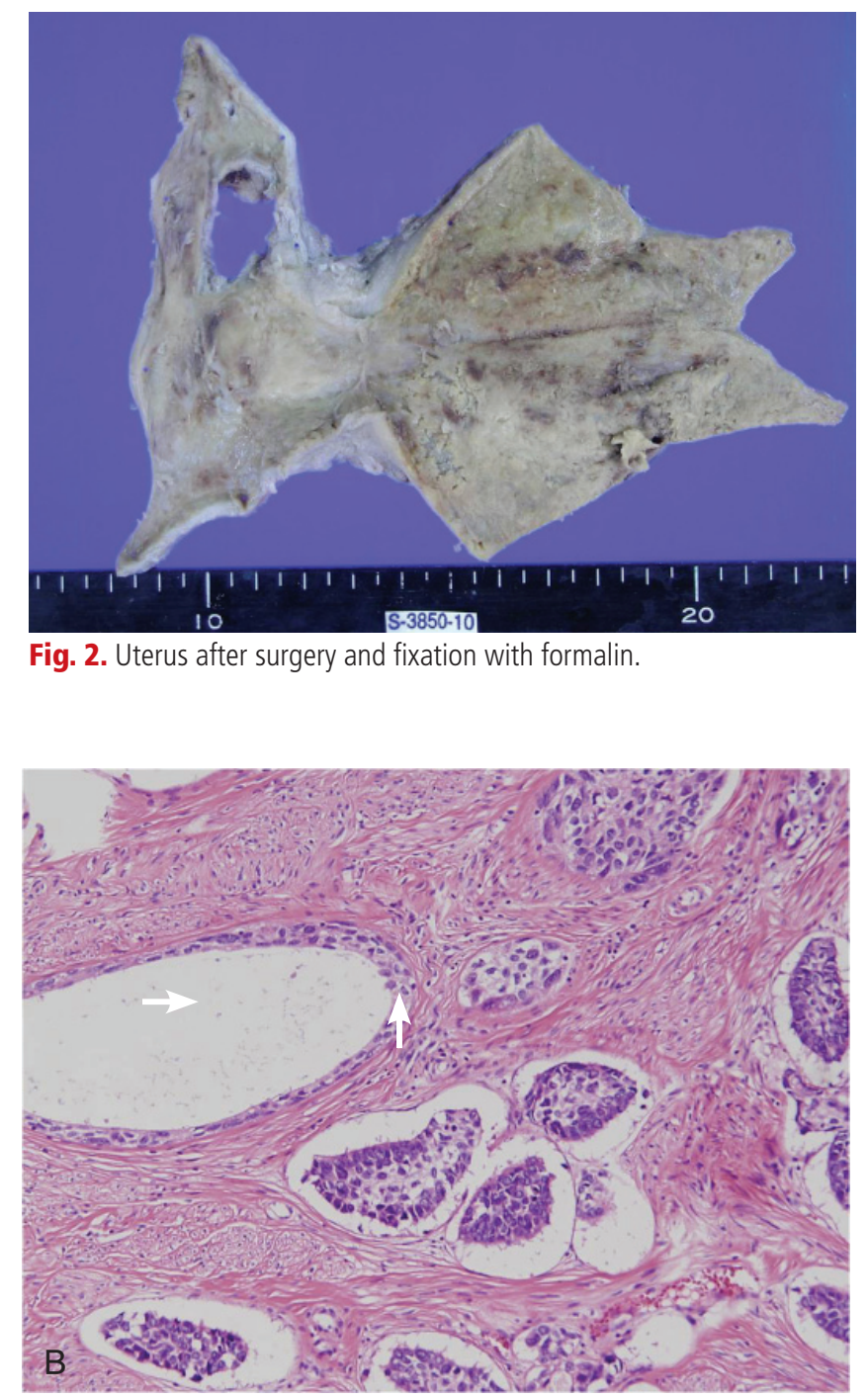

Fig. 2. Uterus after surgery and fixation with formalin.

직 검사에서 특이 소견 보이지 않아 항생제 치료, 자궁 내 농양 흡입술 시행 후 복강경하 자궁 절제술을 시행하기로 하였다. 수술 시 골반이나 복강 내의 이상 소견은 관찰되지 않았으나 떼어낸 자궁 내경부 조직이 육안상 연화된 소견을 보여 응급동결검사 의뢰하였으며 고등급 편평상 피내병변(high grade squamous intraepithelial lesion) 이상의 소견이 관 찰되어 영구 조직 검사 확인해 보기로 하고 복강경하 자궁 절제술 및 양 측 부속기 절제술을 시행하였다.

병리학적 소견:

1. 고정 후 소견: 절제한 자궁은 길이 $11.0 \mathrm{~cm}$, 너비 $6.5 \mathrm{~cm}$, 두께 1.0 $\mathrm{cm}$ 이었고 자궁 경부는 여러 군데 헐어 있는 상태였으며 자궁 내막에는 딱지 같은 물질들이 침착되어 있었다(Fig. 2).

2. 현미경 소견: 소량의 세포질과 진한 핵상을 띄는 작고 고른 크기의 세포들이 둥지 형태를 이루며 자궁 근층을 침습한 소견 보였다. 변연부 
의 세포가 열을 지어 울타리 모양으로 배열되는 전형적인 선양기저세포 암의 소견을 보였으며, 기저 세포들 옆으로 선세포가 관찰되었다(Fig. 3). 임상적 경과: 수술 후 영구 조직검사 상 종괴가 자궁 경부에 국한된 $4.0 \mathrm{~cm}$ 미만의 크기로 혈관/림프절 전이 소견 없고 변연 조직 깨끗하 여 병기 Ib1으로 설정하고 보존적 치료 시행 후 전신 상태 호전되어 퇴 원하였다. 수술 일주일 뒤 외래 방문 시 특별히 호소하는 증상은 없었 고, 이후 검사한 양전자방출단층촬영술(positron emission tomographycomputed tomography)상 골반강 내 병소 제거된 상태로 대사 증가된 부위 없었으며 타 장기에 전이 소견 보이지 않아 추가적 치료 없이 본과 에서 외래 통해 경과 관찰 중에 있다.

\section{고 찰}

자궁 경부의 선양기저세포암은 전 세계적으로 매우 드문 종양으로 아 프리카계 미국인 폐경기 여성에게 흔하다고 알려져 있으나 최근에는 아 시아인에게도 종종 보고되고 있는 추세이다. 한국에서도 1999년 Park 등[5]과 2003년에 Lee 등[6]이 자궁 경부의 선양기저세포암을 경험 한 사례를 발표한 바 있다. 선양기저세포암은 상피 아래 위치하여 발견 이 매우 어려우며 육안상으로도 정상 자궁 경부로 보이거나 뚜렷한 형 태의 병변을 보이지 않는 경우가 많다[4]. 간혹 선별 검사에서 발견되 는 경우에는 대부분이 고등급 편평상피내병변으로 나타난다[3]. 조직 학적으로 작고 둥근 세포들이 둥지 형태를 이루며 증식하는 특징을 보 이고 그 세포들은 비교적 크고 진한 핵과 적은 양의 세포질을 갖는다 [2,7]. 면역조직화학적으로 종양은 기원하는 조직에 존재하는 keratin에 염색 양성 소견을 보여 종양 표지자로 사용 가능하다. 자궁 외경부 편 평 상피의 기저 세포는 CK 14, 19 에 양성이며 자궁 경부의 선양 기저세 포암은 대표적으로 CK 14, 17, 19 와 cytokeratin KL1에 염색 양성 소견 을 보인다[8,9]. 본 사례에서도 면역 염색에서 CK와 p63에 양성 소견을 보였다. Grayson 등[2]의 연구에서 자궁 경부의 선양낭포암이 epithelial membrane antigen (EMA) 및 collagen $\mathrm{V}$ 와 laminin에서 모두 양성 소 견을 보인 반면 선양기저세포암은 EMA에는 모두 양성, collagen IV와 laminin에는 모두 음성 소견을 보였다[8,9]. 유전적인 연구에 의하면 선 양기저세포암는 종종 인체 유두종 바이러스와의 관련성이 보고되기도 하며 Jones 등[10]의 연구에서 p53 gene의 변형과 관련된 연구 결과도 있었다[11]. 선양 기저세포암은 세포의 증식이 늦기 때문에 전이나 재발 이 적어 예후가 좋다고 알려져 있어 상대적으로 예후가 더 좋지 않은 선 양 낭포암과의 감별이 매우 중요하다. 선양 낭포암은 조직학적으로 선 양 기저세포암과 매우 유사하나 세포의 이형성, 유사분열, 괴사, 실질의 유리화, 전이 등이 흔하다는 것에서 차이점을 찾을 수 있다[2]. 또한 선 양 낭포암은 임파구나 형질 세포의 침습이 많아 임파선 침윤이나 전이 를 동반하는 경우가 많으므로 광범위 자궁절제술 및 보조적인 항암 요 법이나 방사선 요법이 필요하며 예후도 좋지 않다[2,4,5,11,12]. 반면 선 양 기저세포암의 예후가 좋지 않은 예는 거의 없으며, 1988년 Ferry와 Scully [13]가 보고한 67세 여성이 폐 전이를 동반하여 3개월 내에 사망
한 1 예가 있을 뿐이다. 자궁 경부의 선양 기저세포암은 대부분 광범위 자궁절제술 치료만으로 좋은 예후를 보인다[14]. 본 사례에서 환자는 농 성 질 분비물을 주소로 내원하여 초음파에서 관찰되는 저에코성 병변 이외에 특이 소견을 보이지 않았고, 내원 3개월 전 개인 병원에서 검사 한 자궁경부 세포진 검사와 본원에서 시행한 자궁 경부 세포진 검사 및 자궁 외경부 조직 검사에서 특이 소견 보이지 않아, 저자들은 농자궁증 의 진단하에 항생제 치료 후 복강경하 질식 자궁절제술 및 양측 부속기 절제술을 시행하였고 이후 조직 검사상에서 자궁 경부의 선양 기저세포 암을 발견하여 이를 문헌 고찰과 함께 보고하는 바이다.

\section{References}

1. Baggish MS, Woodruff JD. Adenoid-basal carcinoma of the cervix. Obstet Gynecol 1966;28:213-8.

2. Grayson W, Taylor LF, Cooper K. Adenoid cystic and adenoid basal carcinoma of the uterine cervix: comparative morphologic, mucin, and immunohistochemical profile of two rare neoplasms of putative 'reserve cell' origin. Am J Surg Pathol 1999;23:448-58.

3. Kalof AN, Cooper K. p16INK4a immunoexpression: surrogate marker of high-risk HPV and high-grade cervical intraepithelial neoplasia. Adv Anat Pathol 2006;13:190-4.

4. Lefrancq T, de Muret A, Michalak S, Lhuintre Y, Fetissof F. Adenoid basal carcinoma and adenoid cystic carcinoma of the uterine cervix. Ann Pathol 1997;17:196-9.

5. Park DC, Kim JH, Lee HG, Chung DY, Kim JW, Lew YO, et al. A case of adenoid basal carcinoma in uterine cervix. Korean J Obstet Gynecol 1999;42:1823-6.

6. Lee S, Ahn J, Park S, Shin H, Kim B, Kim M, et al. A case of adenoid basal carcinoma of the uterine cervix. Korean J Obstet Gynecol 2003;46:2534-7.

7. Cviko A, Briem B, Granter SR, Pinto AP, Wang TY, Yang YC, et al. Adenoid basal carcinomas of the cervix: a unique morphological evolution with cell cycle correlates. Hum Pathol 2000;31:740-4.

8. Zamecnik M, Skrivanek A. Adenoid basal epithelioma of the uterine cervix in 21-year-old patient. Report of a case with histologic and immunohistochemical study. Cesk Patol 2005;41:157-62.

9. Senzaki H, Osaki T, Uemura Y, Kiyozuka Y, Ogura E, Okamura $A$, et al. Adenoid basal carcinoma of the uterine cervix: immunohistochemical study and literature review. Jpn J Clin Oncol 1997;27:437-41.

10. Jones MW, Kounelis S, Papadaki H, Bakker A, Swalsky PA, 


\section{KOREAN JOURNAL OF OBSTETRICS \& GYNECOLOGY}

KJOG Vol. 54, No. 2, 2011

Finkelstein SD. The origin and molecular characterization of adenoid basal carcinoma of the uterine cervix. Int J Gynecol Pathol 1997;16:301-6.

11. Takeshima Y, Amatya VJ, Nakayori F, Nakano T, Iwaoki Y, Daitoku K, et al. Co-existent carcinosarcoma and adenoid basal carcinoma of the uterine cervix and correlation with human papillomavirus infection. Int J Gynecol Pathol 2002;21:186-90.

12. Yoshida T, Fujiwara K, Shimizu M, Kohno I, Mikami Y, Manabe
T. Adenoid basal carcinoma of the cervix uteri: a case report. Pathol Int 1997;47:775-7.

13. Ferry JA, Scully RE. "Adenoid cystic" carcinoma and adenoid basal carcinoma of the uterine cervix. A study of 28 cases. Am J Surg Pathol 1988;12:134-44.

14. Phillips GL Jr, Frye LP. Adenoid cystic carcinoma of the cervix: a case report with implications for chemotherapeutic treatment. Gynecol Oncol 1985;22:260-2.

\section{자궁 경부의 선양 기저세포암의 1 예}

\section{조선대학교 의과대학 산부인과학교실}

조영화, 최지현, 정 혁

자궁 경부의 선양기저세포암은 폐경기 여성 주로 발생하는 드문 질환으로 대부분이 특정한 형태의 병변을 보이지 않아 발견이 어렵다. 선 양기저세포암은 전이나 재발이 적어 광범위 자궁절제술만으로 치료가 되는 경우가 대부분으로 조직학적 검사가 유사하나 예후가 좋지 않 은 선양낭포암과 감별이 필요하다. 저자들은 농자궁증의 진단하에 자궁절제술을 시행한 환자의 수술 후 조직학적 검사상, 선양기저세포 암 1 예를 경험하여 이를 보고하는 바이다.

중심단어: 선양기저세포암, 선양낭포암 